\title{
UNIVERSAL PLASMA DEVICE FOR ION-PLASMA SURFACE STRENGTHENING TREATMENT
}

\author{
Institute of Technical Mechanics \\ of the National Academy of Sciences of $U$ kraine and the State Space Agency of U kraine, \\ 15 Leshko-Popel St., D nipro 49005, U kraine; e-mail: G ryshkevych.O.D @ nas.gov.ua
}

\begin{abstract}
This work is devoted to the development of equipment for a combined ion-plasma metal surface strengthening technology. An optimal combination of ion-plasma strengthening technologies should include a technology of modification of the mechanical properties of a metal surface by nitrogen ion implantation (nitriding) and a nanostructured coating deposition technology. The strengthening treatment object was a shaft. An ion-beam technology of high-intensity low-energy nitrogen ion implantation was used for nitriding. The implantation was implemented using an anode-layer ion source (accelerator). For nanostructured coating deposition, the authors chose an ion-plasma technology that uses an unbalanced magnetron sputtering system with a high-current pulsed magnetron discharge (HCPMD). This choice was due to the fact that both an anode-layer accelerator and a magnetron sputtering system use single-type discharges with closed electron drift, which facilitates their vacuum condition compatibility. An integrated system that includes an anode-layer accelerator and a magnetron sputtering system, i.e., independent plasma devices, was tested. That configuration was not found to be optimal because of its bulkiness. It was studied whether it was possible to make a magnetron sputtering system perform functions of coating deposition and collimated gas-metal plasma flow generation. If so, an unbalanced HCPMD magnetron sputtering system would become a universal plasma device for combined strengthening treatment. Experimental studies were conducted to verify the feasibility of this combination of processes with the use of a single upgraded magnetron-type plasma process device. The upgrade was aimed at attaining a high degree of magnetic field unbalance. For this purpose, use was made of an additional magnetic system with an external magnetic coil (outside of the vacuum chamber). The HCPMD was powered using a proprietary low-frequency $(100 \mathrm{~Hz})$ switching discharge supply. The local and space characteristics of a gas-metal plasma beam in the drift region were studied. It was confirmed that the plasma beam angle can be varied over a wide range to control the treatment locality degree. The local plasma characteristics attained in the experiments meet the requirements for ion-plasma strengthening treatment. The implantation treatment efficiency was confirmed in a test specimen nitriding experiment, whose results were satisfactory.
\end{abstract}

Keywords ion-plasma technology, high-intensity low-energy ion implantation, nanostructured coating, highcurrent pulsed magnetron discharge, gas-metal plasma, magnetron sputtering system, pulsed discharge power source.

1. Stepanova T. Yu. Technologies of Machine Component Surface Strengthening. Ivanovo: Ivanovo State University of Chemistry and Technology, 2009. 64 pp. (in Russian).

2. Sulima V. A., Shulov V. A., Yagodkin Yu. D. Machine Component Surface Layer and Service Properties. Moscow: Mashinostroyeniye, 1988. 240 pp. (in Russian).

3. Boitsov A. G., Mashkov N. V., Smolentsev V. L. Part Surface Strengthening by Combined Methods. Moscow: Mashinostroyeniye, 1991. 144 pp. (in Russian).

4. Aksenov I. I., Andreeev A. A., Belous A. et al. Vacuum Arc. Plasma Sources, Coating Deposition, and Surface Modification Kyiv: Naukova Dumka, 2012. 727 pp. (in Russian).

5. Kuzmichev A. I. Magnetron Sputtering Systems. Book 1. Introduction to Magnetron Sputtering Physics and Technology. Kyiv: Avers, 2008. 244 pp. (in Russian).

6. Mozgrin D. V., Fetisov I. K., Khodachenko G. V. Experimental study of high-current forms of a low-pressure quasi-steady discharge in a magnetic field, Fizika Plazmy. 1995. V. 21. No. 5. Pp. 422-433. (in Russian).

7. Ehiasarian A. P., Wen J. G., Petrov I. Interface microstructure engineering by high power impulse magnetron sputtering for the enhancement of adhesion. Journal of Applied Physics. 2007. V. 101. 054301.

https://doi.org/10.1063/1.2697052

8. Ivanovsky G. F., Petrov V. I. Ion-Plasma Material Treatment. Moscow: Radio i Svyaz, 1986. (in Russian). 
9. Gryshkevych O. D., Hryniuk S. I. Magnetron formation and use of intensive gas-metal plasma flows. Teh. Meh. 2019. No. 2. Pp. 102-112. (in Russian).

https://doi.org/10.15407/itm2019.02.102

10. Svadkovsky I. V. Lines of magnetron sputtering system development. Doklady BGUIR. 2007. No. 2(18). Pp. 112-121. (in Russian).

11. Belyi A. V., Kukareko G. D., Myshkin N. K. Wear-Resistant Surface Layer Structure and Formation Methods. Moscow: Mashinostroyeniye, 1991. 205 pp. (in Russian).

12. Gryshkevych O. D., Hryniuk S. I. Development and study of a prototype low-frequency power source for a high-current pulsed magnetron discharge. Teh. Meh. 2019. No. 4. Pp. 137-147. (in Russian). https://doi.org/10.15407/itm2019.04.137

13. Kadyrzhanov K. K. Ion-Beam and Ion-Plasma Material Modification. Moscow: Moscow State University, 2005. 640 pp. (in Russian).

14. Gryshkevych A. D. Cylindrical magnetron sputtering system with ion assistance. Teh. Meh. 2013. No. 2. Pp. 109-114. (in Russian).

15. Gryshkevych A. D., Grinyuk S. I., Kovalenko V. V. et al. Plasma process devices based on a discharge with closed electron drift. Teh. Meh. 2013. No. 4. Pp. 43-57. (in Russian).

16. Rogov A. V., Kapustin Yu. V., Martynenko Yu. V. Factors determining the efficiency of magnetron sputtering. Optimization criteria. Technical Physics. 2015 V. 60. No. 2. Pp. 283-291.

https://doi.org/10.1134/S1063784215020206

17. Solov'ev A. A., Sochugov N. S., Oskomov K. V., Rabotkin S. V. Characterization of an unbalanced magnetron sputtering system plasma. Fizika Plazmy. 2009. V. 35. No. 5. Pp. 443-452. (in Russian). https://doi.org/10.1134/S1063780X09050055

18. Ershov A. P. Method of Electric Langmuir Probes. Moscow: Moscow State University Faculty of Physics, 2007. 26 pp. (in Russian)

19. Poolcharuansin P., Bowes M., Petty T. J., Bradley J. W. Ionized metal flux fraction measurements in HiPIMS discharges. Journal of Physics D: Appl. Physics. 2012. No. 45. Pp. 1-5.

https://doi.org/10.1088/0022-3727/45/32/322001

20. Belyi A. V., Kukareko V. A., Lobodaeva O. V. et al. Ion-Beam Treatment of Metals, Alloys, and Ceramics. Minsk: FTI, 1998. 218 pp. (in Russian). 